\title{
Physical mapping of Malacosoma neustria nuclear polyhedrosis virus genome and its modification in Antheraea pernyi cell culture
}

\author{
I. M. Kikhno, L. I. Strokovskaya, R. A. Meleshko, J. Michalic ${ }^{1}$, A. P. Solomko \\ Institute of Molecular Biology and Genetics, National Academy of Science of Ukraine \\ Vul. Zabolotnoho, 150, Kyiv, 03143, Ukraine \\ 1 \\ Department of Protein Blosynthesis, Institute of Blochemistry and Biophysics NAS of Poland \\ A. Pawinskega 5 , 02-106, Warsawa, Poland
}

A physical map of the $M$. neustria nuclear polyhedrasis virus (ManeNPV) genome was constructed, the complete order of BamHI, KpnI and PstI restriction enzyme sites was determined, a polyhedrin gene was localized on the map. The viral DNA size was calculated to be about $139 \mathrm{kbp}$. Restriction endonuclease profiles of the DNA of ManeNPV plaques isolate propagated in A. pernyi cells demonstrated epersistent heterogeneity", submolar bands were shown to appear in a digestion pattern of DNA of the first passage virus. These bands were proved to be due to the DNA molecules presence in the non-homogeneous virus DNA pool, their chains having been shown to carry a putative break in a definite site. Such a "break site* was localized on the physical, map of ManeNPV genome.

The Baculoviridae contain double-stranded circular DNA viruses infecting a lot of species belonging mainly to the Lepidoptera, Diptera, and Hymenoptera orders. Baculoviruses with their large genomes and complex reproduction cycle accompanied by the cascade gene expression regulation have become an interesting and well-made topic of molecular biology studies. The interest to the representatives of this family is also caused by three aspects of their practical use. First of them is an application of the baculoviruses as vectors for gene therapy, the problem being investigated during last decade $[1,2]$. Two other aspects are more traditional: baculoviruses are considered as viral insecticides for pest insect control and are widely used as vectors for recombinant protein synthesis in both in vivo and in vitro cultivated insect cells [3].

M. neustria (Mane) larvae (Lepidoptera, Lasiocampidae) is a well known garden fruit pest insect, especially on apple trees. However, outbreaks of the pest mass reproduction occur often also in woods (first of all, in oak woods) of the forest-steppe zone.

(C) 1. M. XIKHNO, l. I. STROKOVSKAYA, R. A. MELESHKO, J. MiCHALAC, A. P. SOLOMKO, 2002
For example, during such an outbreak in the middle of the XX century many thousands of hectares of Eastern Europe woods were completely deprived of leafage. Currently, Mane populations are controlled by the application of chemical insecticides.

In our laboratory a virus strain has been isolated from a diseased Mane larvae [4]. M. neustria nuclear polyhedrosis virus (ManeNPV) is a species in the genus Nucleopolyhedravirus, family Baculoviridae. It has been adapted to the cell line MCAp-1 derived from $A$. pernyi larvae [5]. Later the ManeNPV polyhedrin gene has been localized in an EcoRI-A fragment of virus genome [6] and complete sequence of this gene has been determined. High productivity of ManeNPV in cultivated MCAp-1 cells as well as a high level of polyhedrin expression in the late infection stage have made this cell-virus system a good candidate for use as an expression system for recombinant protein production under the polyhedrin gene promoter control $[7,8]$. Working with ManeNPV we have detected its interesting feature. Submolar bands have been observed in the REN profiles of virus DNA indicating that the virus isolate used in this study is not homogenous and contains minor genotypic variants. We have failed to select out a homogenous 
virus clone using routine multiple plaque-forming approach, minor submolar bands have been detected in the REN profiles of the DNA of all plaque isolates.

Aiming at usage of ManeNPV as an insecticide and a vector for recombinant protein expression as well as understanding the nature of its unusual «persistent heterogeneity» we have begun to study its genetic organization.

Materials and Methods. MCAp-1 cells were maintained in the Grace's medium supplemented with $10 \%$ heat-inactivated fetal bovine serum. Some details of the cell cultivation, virus propagation, and plaque assay were described previously [9]. Plaque assays were incubated for 4 days at $27^{\circ} \mathrm{C}$. Infected cells and extracellular virus (ECV) fluids for viral DNA extraction, virus stock obtaining and virus titer estimation were made 7 days p. $i$.

Viral DNA from infected cells was isolated according to the method previously described [10] with some modifications. This method permits to obtain supercoiled forms of viral DNA with minimal cellular DNA contamination. DNA was isolated directly from virus-infected cells without preliminary virus purification. To isolate each preparation, $(5-8) \cdot 10^{6}$ cells were suspended in $100 \mu \mathrm{l}$ of $0.05 \mathrm{M}$ EDTA solution. An equal volume of $2 \times$ buffer containing $50 \mathrm{mM}$ EDTA, $0.5 \mathrm{mg} / \mathrm{ml}$ spermidine, $0.4 \mathrm{mg} / \mathrm{ml}$ ethidium bromide was then added. The $\mathrm{pH}$ of this mixture was adjusted to 11.5 with $0.25 \mathrm{M} \mathrm{NaOH}$ and then neutralized with $0.1 \mathrm{M} \mathrm{HCl}, 10 \mu \mathrm{l}$ of RNAse A $(10 \mathrm{mg} / \mathrm{ml})$ was added. After incubation $\left(37^{\circ} \mathrm{C}\right.$, $30 \mathrm{~min}$ ) sodium laurylsulphate was added to the lysate $(1 \%)$ as well as proteinase $\mathrm{K}(1 \mu \mathrm{g} / \mathrm{ml})$. The mixture was incubated overnight at $37^{\circ} \mathrm{C}$. DNA was extracted three times by phenol, one time by chlorophorm and then ethanol precipitated. Alternatively, viral DNA was isolated from infected cells and ECV according to the standard procedures described by O'Reily [9].

Viral DNA was digested with different restriction endonucleases and then run in $0.7 \%$ agarose gel electrophoresis using Tris-borate buffer system [11]. Molecular sizes of the ManeNPV DNA fragments obtained after digestion have been estimated by comparison with phage DNA HindIII/EcoRI/BamHI markers. For high molecular weight fragments the second enzyme was used to generate smaller fragments and to provide better estimation. For this purpose viral REN fragments were separated in $0.7 \%$ low melting agarose gel, gel slices including large fragments were excised, heated to $68^{\circ} \mathrm{C}$, two-fold diluted with TE buffer and digested using appropriate buffer.

DNA probes were labelled with $\left[{ }^{32} \mathrm{P}\right.$ ]dCTP using random primer labelling kit («Fermentas», Lithuania)) according to the manufacturer's protocol. Electrophoretically separated the restriction fragments were transferred to nylon filter (Hybond-N, «Amersham», Great Britain)) and hybridized with labelled probes according to Maniatis [11].

Results and Discussion. Our first step was the construction of the ManeNPV physical map and locating on this map the site the changes of which cause the appearance of submolar bands in electrophoregrams of the digested virus DNA.

One of two ManeNPV strains isolated from Mane larvae - the isolate K2 [4] - was selected for further investigations. The REN digestion pattern of this isolate did not contain submolar bands, therefore we have supposed K2 to have a single genotype. However, the further REN digestion followed by the hybridization of blotted REN fragments with the ${ }^{32} \mathrm{P}$-labelled DNA of the same virus demonstrated low intensity of submolar bands in the digested DNA patterns. As a result of more attentive study of the electrophoregrams obtained we have revealed such submolar bands also in the REN profiles formed after the excessive virus DNA introduction into sample wells. These data are against homogeneity of the clone obtained; so we purified it additionally, three plaque passages were made. Fifteen plaques were selected out during the third passage; each plaque variant was reproduced to obtain virus stocks. These stocks were used for the cell culture infection, the MOI being 5 pfu/cell. The viral DNAs obtained from the reproduced virus isolates were REN digested. We attempted to select out in such a way any virus isolate presenting either a single major or a single minor fraction of the K2 isolate. Among $15 \mathrm{REN}$ digested virus DNA preparations 13 ones were shown to possess submolar fractions. Two virus isolates presented single major fraction following such a treatment. However, after the second in vitro passage of the both isolates their DNAs were not homogenous. It should be noted that «homogeneity" or kheterogeneity» are not strict terms, so-called homogenous DNA samples may contain microquantities of the molecules of minor fraction undetectable by the following REN analysis. All 15 isolates demonstrated the identical heterogenous REN DNA profiles, the only difference concerned the submolar bands intensity. An isolate, W1 (referred then as ManeNPV), was chosen among 15 ones for further investigations because of the higher intensity of its minor bands comparing to the minor bands of other isolates. Our investigations have shown the constant quantity and size of the ManeNPV submolar fragments for each restriction endonuclease used; they do not depend on 
A

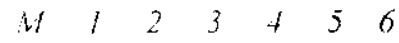

$B$

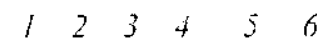

C

$123+56$

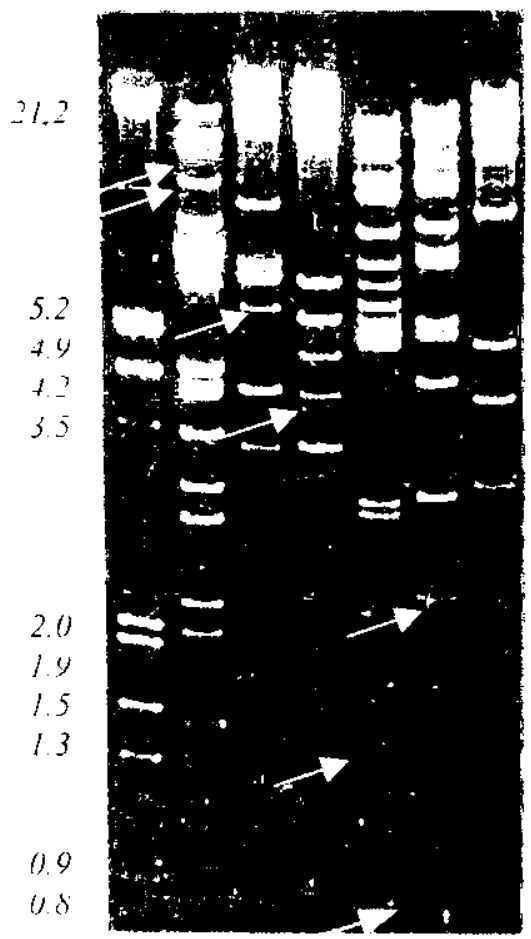

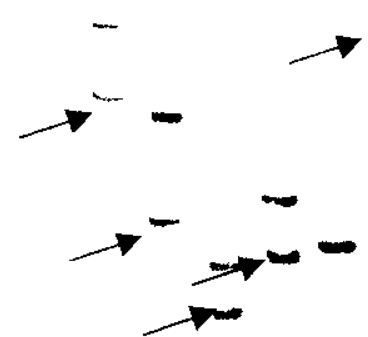

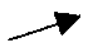

passage number (the virus after $1-10$ passages was taken) and on MOI $(0.1,1.0,10.0)$. Two bands appeared after the EcoRI, BamHI, KpnI, BgllI treatment; one band after HindIII treatment and no submolar bands were found after the PstI action (see fig. $1, A$ ).

The virus population heterogeneity is not a unique phenomenon. Natural baculoviral populations contain different genotype variants which can be cloned out using the cell culture methods. However, such a cloned and «originally» homogenous virus strains are shown to be changed after their passages in vitro, new patterns having been detected in the REN profiles of genome DNAs of virus plaque isolates originated from such strains. Previous studies with the serial passage of cloned virus have shown that DNA insertions and deletions are relatively common in the baculovirus genome. The REN analysis of baculovirus genomes has revealed several types of genomic alterations occuring upon serial passages in vitro. In some cases viruses isolated from a serially passaged stock virus carry a host-derived transposable element insertion $[12,13]$. In other cases the viral plaque isolates selected from the serial passaged stock contain viral DNA insertions at reiterated regions of the viral genome [14]. Some baculovirus deletion mutants have been recorded to appear also after the in vitro passaging of undiluted virus stocks $[15]$.

Accumulation of defective interfering particles in the serially passaged virus stock is detected in the REN profiles of DNA prepared from this stock. The restriction fragments from deleted regions are present in submolar quantities in the REN profiles of heterogenous virus DNA preparations. In this case submolar bands are seen in the REN patterns of virus DNA after serial passages, usually with high MOI. A striking property of the ManeNPV is its «persistent heterogeneity» detected already after the first passage by virus materials of low MOI.

Comparing our data with the results of other authors would not be adequate because of the special method of cellular virus (CV) DNA isolation used. Besides, other data concerning the baculovirus heterogeneity are usually based on the analysis of DNA isolated from the ECV. To rule out any artifact due to the specificity of the DNA extraction method, we 
PHYSICAL MAPPING OF MALACOSOMA NEUSTRLA

have compared the REN profiles of the DNAs isolated from $\mathrm{CV}$ using both our protocol and the standard common one. All of the DNA samples always possessed minor submolar bands regardless of the protocol used. We have also analyzed the baculovirus DNA isolated by the alkali-ethidium method from the Spodoptera frugiperda (Sf9) cells infected by the Autographa californica NPV. The electrophoresis of the REN-digested DNA of this virus has not revealed any new bands (data not shown). We have also compared the digested ManeNPV DNAs isolated from the cells and from ECV. The REN analysis has demonstrated the identity of samples obtained and the presence of minor bands in both of them (data not shown). All these data, having been taken into consideration, suggest our results to be independent of the specificity of the alkali-ethidium DNA isolation protocol, although any artifact cannot be ruled out.

To continue the study of the factors causing this phenomenon first of all we had to answer the question what kind of alterations contains the minor genotypic variant comparing to the major genotypic one. Therefore, the ManeNPV physical map had to be constructed. In our following investigations concerning the physical mapping of the ManeNPV major fraction genome we used heterogenous ManeNPV DNA. The DNA samples were treated with the BamHI, KpnI, and $P$ stI restriction endonucleases. The electrophoretic patterns obtained are shown in fig. $1, A$ (lanes 1 , 2,6 correspondingly) and fig. 2. We obtained 10 BamHI-fragments including also two submolar fragments, $11 \mathrm{KpnI}$-fragments including two submolar ones, and 9 Ps $t$-fragments. The fragment sizes are given in the table. Some highly molecular weight fragments obtained (BamHI-A, B, C; KpnI-A,C,D) were treated in addition with PstI, KpnI, BamHI, or EcoRI. Their sizes were calculated as a sum of the fragments obtained.

We also performed a double ManeNPV digestion using the BamHI-KpnI, BamHI-PstI, KpnI-PstI combinations (data not shown). As a result the full genome size was determined to be of about $139 \mathrm{kbp}$. The DNA-DNA hybridization technique was used to construct a physical ManeNPV genome map. The BamHI-fragments extracted from the gel or cloned into $p U C / 8$ ( $F$ - and $G$-fragments) were labelled and hybridized to Southern blots of viral DNA digested by KpnI and PstI. The order of respective restriction sites was confirmed by the direct comparison of single and double digests on agarose gels and by comparison of the sizes of individual single-digest fragments with the sizes of double-digest fragments. According to the proposal [16], the smallest fragment containing a putative polyhedrin gene should be taken as a zero
Size of the restriction endonuclease fragments of Malacosoma neustria NPV

\begin{tabular}{|c|c|c|c|c|c|}
\hline \multicolumn{2}{|c|}{ BamHI } & \multicolumn{2}{|c|}{ Kpnt } & \multicolumn{2}{|c|}{ Pstt } \\
\hline Fragment & kbp & Fragmeat & kbp & Fragment & kbp \\
\hline$A$ & $68.1^{*}$ & $A$ & $54.8^{*}$ & $A$ & $44.1^{*}$ \\
\hline$B$ & $21.4^{*}$ & $B$ & 27.0 & $B$ & 22.0 \\
\hline$C$ & $17.2^{*}$ & $C$ & $21.2^{*}$ & $c$ & 21.0 \\
\hline$D$ & 8.9 & $D$ & $15.4^{*}$ & $D$ & 17.2 \\
\hline$m 1$ & 5.5 & $E$ & 6.3 & $E$ & 14.0 \\
\hline$E$ & 6.6 & $F$ & 5.2 & $F$ & 8.7 \\
\hline$F$ & 6.3 & $G$ & 4.6 & $G$ & 4.7 \\
\hline$G$ & 6.3 & $m 1$ & 4.1 & $\boldsymbol{H}$ & 4.0 \\
\hline$H$ & 4.1 & $H$ & 3.4 & $I$ & 2.9 \\
\hline$m 2$ & 3.4 & $I$ & 0.9 & - & - \\
\hline - & - & $m 2$ & 0.5 & - & - \\
\hline Total & 138.9 & Total & 138.7 & Total & 138.6 \\
\hline
\end{tabular}

The size of the genome as estimated by the sum of the restriction fragments (submolar fragments, indicated as $m 1$ and $m 2$ were not inciuded in the sum) is shown at the bottom of each column. *Restriction endonuclease fragment has been cleaved.

point on the physical map of baculovirus DNA. We have earlier cloned the EcoRI-A-fragment of the ManeNPV genome containing the polyhedrin gene [6], a physical map of the given plasmid was constructed. The comparing of physical maps of the ManeNPV genome and its EcoRI-fragment has permitted to locate the full polyhedrin gene in the PstI-C-fragment. This fragment was taken as a zero point of the linearized circular map. The linear BamHI, KpnI, and PstI physical maps of the genome of the major fraction of ManeNPV are shown in fig. 3.

The BamHI and $K p n I$ minor fragments were also located on this map. Our results of blot-hybridization have shown the BamHI-mI and $m 2$ minor fragments ( 5.5 and $3.4 \mathrm{kbp}$ correspondingly) to be components of the BamHI-D-fragment of $8.9 \mathrm{kbp}$ size. The $K p n I-m I$ and $m 2$ minor fragments $(4.1$ and $0.5 \mathrm{kbp}$ correspondingly) were included into the $K p n I-G$-fragment $(4.6 \mathrm{kbp})$, in other words an additional site for every restriction endonuclease was present on the physical map of the minor variant of ManeNPV genome. The localization of submolar components on the physical map of the ManeNPV DNA has proved the additional sites for BamHI and KpnI to be situated in the same locus of this map (indicated by 


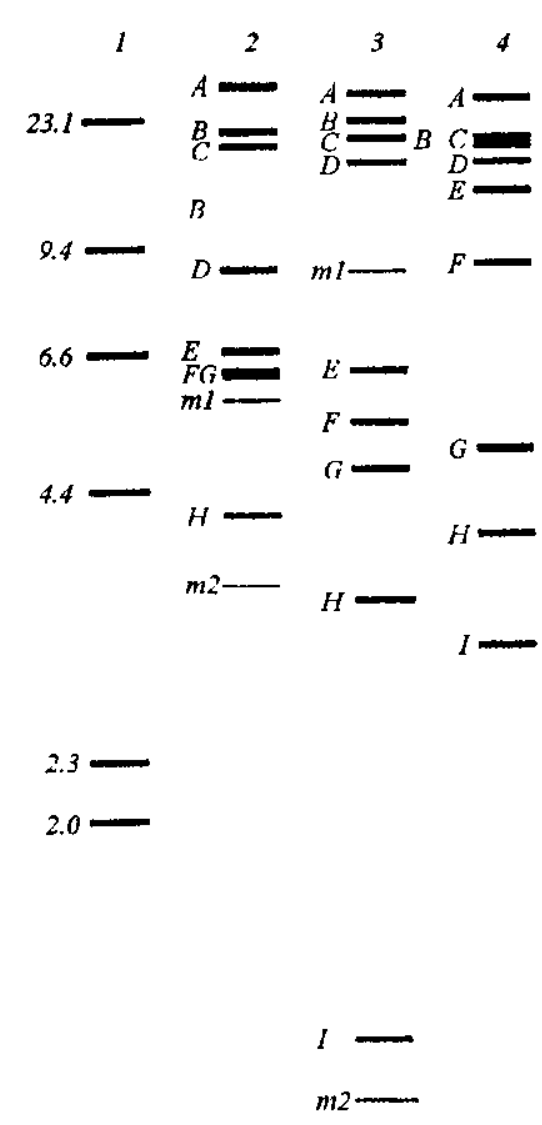

Fig. 2. Diagram of the REN profiles of ManeNPV digested with BamHI (2), KpnI (3), PstI (4) and HindIII-cleaved (phage DNA standards $(J))$

arrow in fig. 3) which coincids with the PstI recognition site. Co-location of the sites for three casually chosen restriction endonucleases has permitted us to suppose this point to be not a specific recognition site for each one, but a site of non-specific or specific virus DNA break. To confirm this idea, we had to locate in the virus genome some submolar fragments obtained after digestions with other restriction endonucleases.

The results of the blot-hybridization experiments (fig. $1, B, C$ ) demonstrated without any doubt that the sums of minor fragments sizes obtained after the $E c o R I$ and BglII digestions corresponded to the sizes of higher molecular fragments hybridizing with ${ }^{32} \mathrm{P}$ labelled $B a m H I$ minor fragments $(10 \mathrm{kbp}+14 \mathrm{kbp}=$ $=24 \mathrm{kbp}$ for $E c o R I ; 2.0 \mathrm{kbp}+0.9 \mathrm{kbp}=2.9 \mathrm{kbp}$ for $B g l I n$. Earlier we have mentioned the lack of the second submolar band in the HindIII-digested viral DNA electrophoregrams (fig. $1, A$ ). The submolar band of $4.8 \mathrm{kbp}$ has been shown by hybridization (fig. $1, B, C)$ to be present in the HindIII REN pattern in

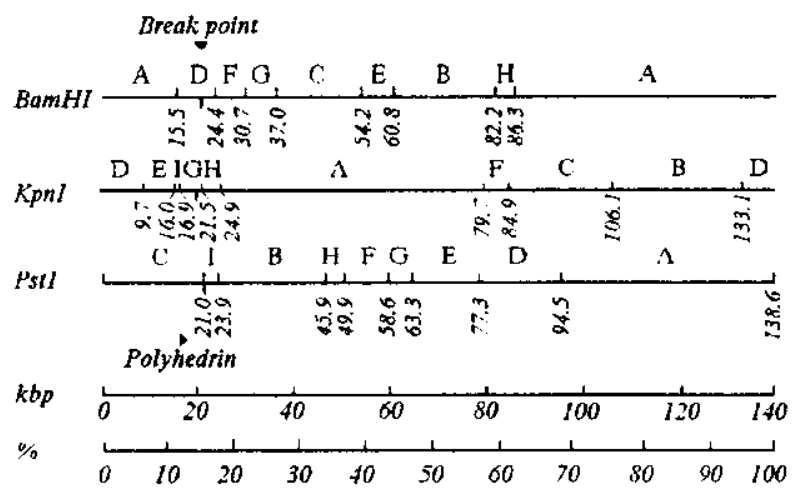

Fig. 3. Physical BamHI, Kpnl and PstI maps of the ManeNPV DNA. Letters correspond to the fragments in fig. 2 and the table. The arrows indicate the position and direction of the polyhedrin gene and position of the kbreak point

major fraction fragments of the same size as hidden. These HindIII submolar fragments sizes sum $(4.8 \mathrm{kbp}+1.3 \mathrm{kbp})$ corresponded to the size of the HindIII-fragment hybridizing with the probes $(6.3$ kbp). We could not locate the EcoRI, HindIII and BglII-fragments directly on the ManeNPV physical map as the recognition sites for these restriction enzymes were not ordered in the full ManeNPV genome. However, the comparison of the full-size physical map and the mentioned EcoRI-A-fragment map has shown that both BamHI-D and KpnI-Gfragments are included in the $E c o R I-A$-fragment giving us a possibility to locate the break point on the EcoRI-A-fragment map. To confirm our hypothesis concerning the existence of this point, we have analyzed the order of BglII and HindIII sites inside the $E c o R I$-A-fragment.

Our results have demonstrated that a possible break point is localized inside the $2.9 \mathrm{kpb}$-fragment dividing it into two parts of 2.0 and $0.9 \mathrm{kpb}$. The HindIII-fragment $(6.1 \mathrm{kpb})$ is also a part of the $E c o R I-A$-fragment and is divided by the break point into two fragments -1.3 and $4.8 \mathrm{kpb}$. Two minor EcoRI-fragments of $14.0 \mathrm{kpb}$ and $10.0 \mathrm{kpb}$ may be a result of the $E c o R I$-fragment $(24.0 \mathrm{kpb})$ damage at the same point. All these results confirm the break point in the site located at a distance of approximately $21.0 \mathrm{kbp}$ from the zero point on the ManeNPV physical map. To locate this site more precisely and to determine the distance from the PstI site, we have made the additional double REN digestion of the virus DNA using BamHI, KpnI, HindIII, BglII combined with $P$ stl, the REN products being hybridized with the labelled BamHI fragments $(3.4$ and $5.5 \mathrm{kpb})$ (data not shown). According to these results, the 
break point is situated at a distance less than $0.1 \mathrm{kbp}$ downstream the PstI site. This fact explains the «absence» of submolar bands on the PstI REN pattern in fig. $1, A$. The $21.0 \mathrm{kpb}$-fragment and the submolar fragment are almost of the same size, the difference being less than $0.1 \mathrm{kpb}$; so it is beyond the differential ability of the REN analysis. The second band corresponding to the second minor component (less than $0.1 \mathrm{kpb}$ ) is of a very low intensity and cannot be detected even by blot-hybridization approach.

Having detected the break in the minor DNA fraction we are now to answer the question if such break is «naturally» present in a part of virus DNA molecules (before DNA isolation) or it appears as a result of the DNA molecule damage during its extraction and purification since some DNA molecules are damage-sensitive in a determined specific point. Our similar results with the virus DNA isolation using different protocols do not rule out this last possibility because each of them includes a phenol-chloroform extraction stage able to damage the DNA molecules. We have found that the use of more «unfavorable» conditions of DNA purification (longer phenol-chloroform extraction procedure and more intensive mixing) causes the increasing of total quantity of damaged DNA molecules and, as a result, the smearing of the REN DNA profiles, the intensity of minor bands having, however, no tendency to increase. According to these data the most probable situation is the existence of a minor virus variant carrying breakcontaining genomes. Any two-stranded DNA break is known to disclose a supercoiled DNA and form linear DNA molecules. However, the circular DNA form is well known to be a natural feature of any baculovirus life cycle, no undamaged «natural» linear forms having been found for any baculovirus studied. Some facts suggest ManeNPV is a typical baculovirus with a typical genome. First, any virus DNA isolation using the alkali-ethidium approach permits to obtain only supercoiled molecules, all the linear ones being destroyed by the alkali treatment. The presence of the linear molecules in such samples is proved to be a result of the following chloroform-phenol deproteinization. Further, such break-containing viral genomes have been shown to be presented not only in the infected cells, which can contain any forms of viral DNA but in the ECV too. The linear viral genomes seem incapable to be packed into maturing particles and to form virions. These data and considerations develop a clear contradiction: it goes that the viral genome integrity is damaged but this genome exists simultaneously as a supercoiled structure. This contradiction may be explained by a hypothesis that any
DNA molecule of the minor genotypic virus variant really contains a break. However, the molecule is stabilized by a protein or proteins, hence a protein «locken ties both ends of the DNA molecules. Such protein(s) are destroyed during the DNA deproteinization and phenol-chloroform treatment causing the DNA linearization.

As we have already discussed usual accumulation of modified virus genomes in a virus clone seeming originally homogenous is a stepwise process following virus passages. The fact that the heterogeneity of the plaque ManeNPV isolates is seen in the first passage virus with low MOI testifies that the term «modification» is hardly applied to this phenomenon. The nature of changes detected here $-a$ break at a determined point of the DNA sequence-permits to make an assumption, that it is not the modification in a strict sense of this word, which means some changes comparing with the natural state, but a phenomenon, which can reflect a natural step of the ManeNPV intracellular reproduction. Our data permit only to make some speculations and to suppose an important functional role of the break point - for example, during replication and/or recombination process or other processes requiring DNA strands break. Some reparation processes are possibly realized with low effectiveness in the virus-cell system studied here, so the break-containing DNA molecules are easily detected in the virus DNA pool.

Either the DNA molecule break is a result of high damage sensitivity of its locus during purification or it is masked by protective protein «naturally» present in baculovirus genome - in any case, this unusual phenomenon is of great interest and to be studied in future.

Ј. М. Кіхно, Л. І. Строковська, Р. А. Мелеико, Ж. Михайлик, о. П. Соломко

Фізичне картування геному вірусу ядерного поліедрозу Malacosoma neustria i його модифікація в клітинній культурі Antheraea pernyi

\section{Резюме}

Складено фізичну карту геному вірусу ядерного поліедрозу $M$. neustria (ManeNPV), визначено розтаиування сайтів для реcmpuкmaз BamHI, KpnI ma Pstl, на карті локалізовано zен поліедрину. Розмір вірусної ДНК визначено приблизно в 139 muc. п. н. Профілі рестриктів ДНК MaпеNPV, ізольованих з бляиок, отриманих у клітинах A. ретпуі, демонструють "тривку гетерогенність", субмолярні фрагменти виявлено в патттерні рестрикцї̈ після периюго пасаху вірусу. Встановле но, що ці фрагменти присутні в пулі гетерогенної вірусної ДНК, а ӥ митки мають розриви в певному місиі. Таке місие розриву було локалізовано на фізичній карті геному ManeNPV. 
KIKHNO I. M. ET AL.

И. М. Кихно, Л. И. Строковская, Р. А. Мелешко, Ж. Мuхайиих, A. П. Соломко

Физическое картирование генома вируса ядерного полиэдроза Malacosoma neustria и его модификация в клеточной структуре Antheraea pernyi

Резюмс

Составгена физическая карта генама вируса ядерного полиздроза M. neustria (ManeNPV), onpedeлено распалохение сайmos drя ресmpuкmas BamHI, Kpnl u Pstl, на карте rокализосан ген полиздрина. Размер вирусной ДНК определен приблизительно в 139 mok. n. th Iрофили рестрикmoe ДHК ManeNPV, usолиросанных из бгашек, полученных в клетках A. ретпуі, демонстрируют кустойнивую гетерогенностьн, субмолярные фрагменты обнарулены в паттерне рестрихиии после первого пассажа sируса. Установгено, что зти фрагменть присутствуют $в$ пуле гетерогенной вирусной ДНК, а ее нити имеют разрыв 6 определенном месте. Тахое место разрыва было локализовано на физической карте генома ManeNPV.

\section{REFERENCES}

1. Hoffmann C., Sandig V., Jennings G., Rudolph M., Schlag P., Strauss $M$. Efftcient gene transfer into human hepatocytes by baculovirus vectors // Proc. Nat. Acad. Sci. USA.-1995.92.-P. 10099-10103.

2. Palombo F., Monciottl A., Recchia A., Cortese R., Ciliberto $G$., La Monica $N$. Site-specific integration in mammallan cells mediated by a new hybrid baculovins-adeno-assoctated virus vector // J. Virol.-1998.-72.-P. 5025-5034.

3. Miller $L$ K. Baculovirus as gene expression vectors // Ann. Rev. Microbiol.-1988.-42.-P. 177-179.

4. Skuratovskaya I. N., Strakovskaya L I., Comissarenko S. V., Mendeleva $N$. V. Structure and function of the Malacosoma neustria nuclear polyhedrosis virus genome // Tsitologia I Genetika. - 1986.-20.-P. 31-36 (in Rusolan).

5. Miloserdova $V . D$., Sukhorada $E$. $M$. Insect cell cultures application for nuclear polyhedrosis vinus investigation // Insect viruses and their practical use.-Kiev: Naukova Dumka, 1979. -P. $59-69$.

6. Strokovskaya L. I., Veselowsky O. V., Kikhno I. M., Mirjuta
N. Yu. Cloning of the Malacosoma neustria nuclear polyhedrosis virus polyhedrin gene // Blopolimery i klitina. 1990.-6.-P. 81-83 (in Russtan).

7. Strokovskaya L. I., Kikhno I. M., Kalinina N. O., Chashchina $L$ I., Solomko A. P. Expression of heterologous proteins in the baculovirus vector system: Malacosoma neustria nuclear polyhedrosis virus - Antheraea pernyi cells // Tsitologia i Genetika. $-1996 .-30 .-P .42-48$.

8. Strokovskaya L I., Kalinina N. O., Kikhno I. M., Solomko A. $\boldsymbol{P}$. Recombinant human prolactin gene expression in insect cells using baculovirus vector based on Malacosoma neustria nuclear polyhedrosis virus // Dopovidi Academil Nauk Ukraini.1997.-1.-P. 166-169 (in Russian).

9. O'Reily D., Miller $L$. K. Luckow $V$. A. Baculovinus expression vectors.-New York: W. H. Freeman and company, 1992.

10. Cherepento E. I., Martinenko E. I. Baculovirus DNA isolation by simple method $/ /$ Molecular Blology.-1985.-19.P. 1519-1524 (in Russian)

11. Maniatis $T$., Fritsch $E$. F., Sambrook J. Molecular cloning: A laboratory manual.-New York: Cold Spring Harbor Lab. publ., $1982 .-452 \mathrm{p}$.

12. Miller $D$. $W$., Miller $L K$. A virus mutant with an insertion of a copia-like transposable element // Nature.-1982.-299.P. $562-564$.

13. Fraser M. J., Smith G. E., Summers M. D. Acquisition of hos cell DNA sequences by baculoviruses: relationship between host DNA insertion and FP mutants of Autographa californica and Galleria mellonella nuclear polyhedrosis virus $/ / \mathrm{J}$. Virol.1983.-47.-P. 287-300.

14. Burand J. P., Summers $M$. D. Mapping the mutation site of an Autographa californica nuclear polyhedrosis virus polyhedron morphology mutant // J. Virol.-1982.-43.-P. 809-818.

15. Kumar $S .$, Miller $L K$. Effects of serial passage of Autographa californica nuclear polyhedrosis virus in cell culture // Vir Res.-1987.-7.-P. 335-349.

16. Vlak J. M. Smith $G$. $E$. Orientation of the genome of Autographa californica nuclear polyhedrosis virus: a proposal // J. Virol.-1982.-41.-P. 1118-1121.

УДК 577.29

Надійшла до редакцї 26.10.2000 